\title{
Water balance output components are distinctly regulated by precipitation and evapotranspiration in Pinus taeda L. plantations in Southern Brazil
}

\author{
As componentes de saída do balanço hídrico são distintamente reguladas pela \\ precipitação e evapotranspiração em plantações Pinus taeda L. no sul do Brasil
}

\author{
Daniela Jerszurki $^{1}$, Jorge Luiz Moretti Souza ${ }^{2}$ e Valentin Couvreur ${ }^{3}$
}

\begin{abstract}
Resumo
O conhecimento do impacto das variáveis climáticas na estimativa do balanço hídrico tem papel fundamental na estimativa de períodos críticos de deficiência ou excesso de água no solo. Teve-se por objetivo no presente trabalho estabelecer as relações funcionais entre a deficiência hídrica, excedente hídrico e armazenamento de água no solo com as variáveis precipitação e evapotranspiração, por meio de análises de balanço hídrico para a cultura do Pinus, na região Sul do Brasil. Foram utilizados 31 anos de dados diários de precipitação $(P)$ e evapotranspiração de referência $(E T o)$ como componentes de entrada no modelo de balanço hídrico de Thornthwaite e Mather modificado. As relações funcionais entre P e ETo e as componentes de saída do balanço hídrico foram identificadas a partir da análise de componentes principais. $O$ déficit hídrico foi influenciado pela sazonalidade da evapotranspiração, dependendo da disponibilidade de água no solo. A P determinou a variabilidade sazonal do excedente hídrico, sugerindo a possibilidade de sua estimativa a partir da própria P. O armazenamento de água no solo não foi diretamente influenciado pela $\mathrm{P}$ ou ETo.
\end{abstract}

Palavras-chave: Análise de componentes principais, estimativa, relações hídricas, relações funcionais.

\begin{abstract}
The knowledge about the impact of climate variables on estimated water balance hold significant promise for the estimation of critical periods of soil water deficit or surplus. Here we establish the functional relations between water deficit, water surplus and soil water storage with precipitation and evapotranspiration for Pinus, in Southern Brazil. For that purpose a 31-years daily data series of precipitation $(P)$ and reference evapotranspiration (ETo) were used as input components of the modified Thornthwaite and Mather water balance model. Principal component analysis was performed as an exploratory analysis of the water balance components related to P and ETo. The water deficit was mostly affected by the seasonality of evapotranspiration depending on soil water availability. The sole effect of $P$ on water surplus (WS) determined its variability and showed the possible use of $P$ to estimate WS. Soil water storage was not directly influenced by P or ETo.
\end{abstract}

Keywords: Principal component analysis, estimate, soil-water relations, functional relations.

\section{INTRODUCTION}

The genre Pinus has been extensively used around the world (PRACIAK et al., 2013) and silvicultural activities became more intensive after 1960, when large-scale pine plantations were established in many regions, representing a major economic importance in their primary growing areas, especially in Southern Brazil, such as Parana state $(A B R A F, 2013)$. Brazil is among the world's largest pine-growing countries and Southern Brazil accounts for more than $76 \%$ of the total pine forest cover in the country country (ABRAF, 2013; ROSA et al., 2006). Given the tremendous economic importance of pine production in Southern Brazil, the current expansion in productivity in the country creates a need to improve the understanding about the occurrence of soil-water critical periods, such as water deficit and surplus.

${ }^{1}$ PhD in Soil Science. UFPR - Universidade Federal do Paraná. Agrarian Sciences Sector. Funcionários Street, 1540 80035050 - Curitiba, PR, Brasil. E-mail: dani jerszurki@hotmail.com.

${ }^{2}$ Associate Professor at Department of Soils and Agricultural Engineering. UFPR - Universidade Federal do Paraná. Agrarian Sciences Sector. Funcionários Street, 1540 - 80035050 - Curitiba, PR, Brasil. E-mail: jmoretti@ufpr.br.

${ }^{3} \mathrm{PhD}$ in Agronomical Sciences and Biology Engineering Université Catholique de Louvain. Place de l'Université 1, 1348. Louvain-la-Neuve, Belgium. E-mail: valentin.couvreur@uclouvain.be.

Sci. For., Piracicaba, v. 46, n. 119, p. 437-448, set. 2018 DOI: dx.doi.org/10.18671/scifor.v46n119.11 
The progressive increase of drought events (IPCC, 2014) constitute one of the most limiting environmental stresses affecting root growth and canopy transpiration (McNULTY et al., 2014). Water availability is recognized as a primary factor in the limitation of leaf area development and growth for pine trees (WARD et al., 2015). In contrast, we also expect rainfall increases of $10-15 \%$ during autumn, ranging up to 25\% in southern Brazil (IPCC, 2014). The surplus of water can also lead to a number of problems, such as reduced productivity and tree mortality, mainly due to poor soil aeration (BELLOTE; DEDECEK 2006). Therefore the soil water content is thought to be one of the most important factors controlling management practices in plantations.

In Brazil, estimated water balance models (EWB) based on climatological data series constitute the most simple and low-cost methodology to evaluate soil-water availability (SOUZA; GOMES 2007). The most accepted model for estimation of water balance in agriculture has been described by Thornthwaite and Mather (1955) (BRUNO et al., 2007; PEREIRA, 2005; SOUZA et al., 2006), which has been widely used and adapted by several authors over time (ARAUJO, 2009; DOURADO-NETO et al., 2010; SOUZA et al., 2016). In this model, the soil-water dynamic is explained in terms of variation of soil water storage $(S)$ over time in response to soil water inputs (precipitation and irrigation) and outputs (evapotranspiration and drainage). The input components are represented by precipitation (P), irrigation (I) and reference evapotranspiration (ETo). The output components are actual evapotranspiration (ETa) and crop evapotranspiration (ETc); water deficit (WD), which is represented by the difference between ETc and ETa, constituting the amount of water that was not evaporated from the soil surface and not transpired from the crop canopy; and water surplus (WS), which is considered equivalent to the soil deep drainage (THORNTHWAITE; MATHER, 1955).

Attempts were made to improve the applicability of EWB's, however, studies relating monitoring of soil water balance components by its sensitivity to climatic variables are still scarce in Brazil. These studies have a key role on understanding the functional relations between soil water balance components and precipitation and evapotranspiration data (GONG et al., 2006; LIQIAO et al., 2008), which can be useful to generate simple alternative models to estimate soil-water critical periods. These results can also be useful for irrigation management of specific crops and areas, planning agricultural activities and climate characterization (KIRKHAM, 2014; LEMOS FILHO et al., 2010; SOUZA; FRIZZONE, 2007). Accordingly, here we aimed to establish the functional relations between water deficit, water surplus and soil water storage with precipitation and evapotranspiration for Pinus taeda L. in Southern Brazil.

\section{MATERIAL AND METHODS}

\section{Climatic data and water balance analysis}

Analyses were performed in Telemaco Borba city (Parana state) in Southern Brazil. Localized on the second plateau of Parana state, the region has climate type transitional humid subtropical to temperate (" $\left.\mathrm{Cfa} / \mathrm{Cfb}^{\prime \prime}\right)$ with an average temperature in the coldest month below $16^{\circ} \mathrm{C}$ including frost events, and an average temperature in the warmest month above $22^{\circ} \mathrm{C}$ (ÁLVARES et al., 2013). Daily data series (January 1981 to December 2010) were provided by a meteorological station installed at coordinates $24^{\circ} 13^{\prime}$ South and $50^{\circ} 32^{\prime}$ West, at $885 \mathrm{~m}$ altitude. The dataset includes the following: precipitation $(\mathrm{mm})$, maximum, minimum and average air temperature $\left({ }^{\circ} \mathrm{C}\right)$, mean relative humidity (\%), daily sunshine hours $\left(\mathrm{MJ} \mathrm{m}^{-2} \mathrm{~d}^{-1}\right)$, and wind speed at ten meters height $\left(\mathrm{m} \mathrm{s}^{-1}\right)$. Daily sunshine hours were measured by heliograph. Daily wind speeds was obtained by anemometer, and transformed to wind speed at $2 \mathrm{~m}$ height by the wind profile relationship (ALLEN et al., 1998). Daily air temperature and relative humidity were obtained by thermometer and humidity sensor, respectively. Precipitation was obtained by use of pluviometer.

Reference evapotranspiration was estimated using the Penman-Monteith equation, developed by the Food and Agriculture Organization of the United Nations - FAO (ALLEN et al., 1998). Crop evapotranspiration (ETc), actual evapotranspiration (ETa), water deficit (WD), water surplus (WS) and soil water storage (S) were obtained in the adapted daily water balance estimated according to Thornthwaite and Mather (1955) methodology by use of historical data series of precipitation (P), reference evapotranspiration (ETo), initial soil water storage, crop coefficient $(\mathrm{Kc})$, total available water (TAW) and fraction of available water (p). 
In order to estimate crop evapotranspiration for a mature pine forest, we used Kc equal to 0.95 (GURSKI et al., 2016), corresponding to the initial, mid-season and end of late season stages. According to Gurski et al. (2016) the Kc $<1$ is better suited to estimate crop evapotranspiration of mature pine forests.

In this study, a 6-year-old pine forest in the mid-season stage was considered. ETc was calculated as follows:

$$
E T c=K c \times E T o
$$

Where ETc is crop evapotranspiration $\left(\mathrm{mm}^{\mathrm{d}} \mathrm{d}^{-1}\right)$; Kc is the crop coefficient (dimensionless); ETo is the reference evapotranspiration $\left(\mathrm{mm} \mathrm{d}^{-1}\right)$.

The soil physical and hydraulic properties, water content at field capacity $\left(\theta_{\mathrm{FC}}\right)$, wilting point $\left(\theta_{\mathrm{WP}}\right)$ and rooting depth were determined in a preliminary field experiment carried out throughout 2009, in five soil layers up to one meter rooting depth (SOUZA et al., 2016) (Table 1).

Table 1. Soil physical and hydraulic properties at rooting depth in a Pinus taeda L. plantation in Southern Brazil (Souza et al., 2016).

Tabela 1. Propriedades físico-hídricas do solo, na profundidade efetiva em uma plantação de Pinus taeda L. no Sul do Brasil (Souza et al., 2016).

\begin{tabular}{|c|c|c|c|c|c|c|c|c|c|}
\hline \multirow{2}{*}{$\begin{array}{l}\text { Layer } \\
\text { (m) }\end{array}$} & Sand & Silt & Clay & C organic & \multirow{2}{*}{$\frac{\rho^{(1)}}{\left(\mathrm{kg} \mathrm{m}^{-3}\right)}$} & Macropores & Micropores & $\alpha^{(2)}$ & \multirow{2}{*}{$\frac{\mathrm{K}_{0}{ }^{(3)}}{\left(\mathrm{mm} \text { day }^{-1}\right)}$} \\
\hline & \multicolumn{4}{|c|}{ 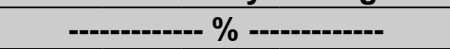 } & & \multicolumn{3}{|c|}{ 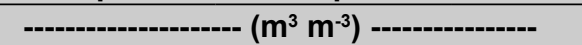 } & \\
\hline $0-0.1$ & 41 & 10 & 49 & 1.70 & $1100 \mathrm{a}$ & $0.200 \mathrm{a}$ & $0.395 \mathrm{c}$ & $0.598 \mathrm{a}$ & $15607.34 \mathrm{a}$ \\
\hline $0.1-0.2$ & 40 & 11 & 49 & 1.20 & $1210 \mathrm{a}$ & $0.137 \mathrm{ab}$ & $0.403 \mathrm{bc}$ & $0.541 \mathrm{a}$ & $4097.95 \mathrm{~b}$ \\
\hline $0.2-0.4$ & 40 & 11 & 50 & 0.89 & 1210 a & $0.140 \mathrm{ab}$ & $0.395 \mathrm{c}$ & $0.537 \mathrm{a}$ & $5651.00 \mathrm{ab}$ \\
\hline $0.4-0.6$ & 36 & 11 & 53 & 0.68 & 1230 a & $0.080 \mathrm{~b}$ & $0.462 \mathrm{a}$ & $0.542 \mathrm{a}$ & $957.20 \mathrm{~b}$ \\
\hline $0.6-1.0$ & 36 & 11 & 53 & 0.45 & $1160 \mathrm{a}$ & $0.116 a b$ & $0.443 a b$ & $0.561 \mathrm{a}$ & $904.80 \mathrm{~b}$ \\
\hline CV $(\%)^{(4)}$ & - & - & - & 5.8 & 6.0 & 24.8 & 3.5 & 4.0 & 71.2 \\
\hline
\end{tabular}

(1)Soil bulk density; (2)Total porosity; ${ }^{(3)}$ Saturated hydraulic conductivity; ${ }^{(4)}$ Coefficient of variation. * Means followed by the same letter do not differ by Tukey $(\mathrm{p}<0.05)$.

The total available water (TAW) was calculated as follows:

$$
T A W=0.01 \cdot\left(\theta_{f z}-\theta_{w p}\right) \cdot z
$$

Where: TAW is total available water $(\mathrm{mm}) ; \theta_{\mathrm{FC}}$ is volumetric moisture in field capacity $\left(\mathrm{m}^{3} \mathrm{~m}^{-3}\right)$; $\theta_{\mathrm{WP}}$ is volumetric moisture in wilting point $\left(\mathrm{m}^{3} \mathrm{~m}^{-3}\right)$; and, $\mathrm{z}$ is the root depth $(1 \mathrm{~m})$.

The readily available water (RAW) was estimated considering a single fraction value $\mathrm{p}(\mathrm{p}=1)$ which includes the conifers group (ALLEN et al., 1998).

$$
R A W=p \cdot T A W
$$

Where RAW is the readily available water $(\mathrm{mm})$; $\mathrm{p}$ is the fraction of total available water in the soil that can be depleted from the root zone before water stress occurs (dimensionless).

The Cosine equation was used to estimate soil water storage (S). According to Dourado Neto et al. (1993) this equation shows the best performance to estimate soil water storage by use of RAW and $\mathrm{p}$ fraction:

If TAW $\times(1-p)<S \leq$ TAW, in wet zone:

$$
S=T A W-L
$$

Otherwise, if $0<\mathrm{S} \leq \mathrm{TAW} \times(1-\mathrm{p})$, in dry zone:

$$
S=(1-p) \cdot T A W \cdot\left\{1-\frac{2}{\pi} \cdot \operatorname{arctg}\left[\frac{\pi}{2}\left(\frac{|L|-T A W \cdot p}{(1-p) \cdot T A W}\right)\right]\right\}
$$

Where: $\mathrm{S}$ is soil water storage $(\mathrm{mm})$, and $\mathrm{L}$ is negative accumulated value $(\mathrm{mm})$ when daily $\mathrm{P}$ is lower than ETc.

The estimated water balance represented by soil water storage variation was calculated yearly as the difference of the soil water storage on the first day of consecutive years (DS). 


\section{Principal component analysis}

The multivariate analysis was carried out by principal component analysis (PCA) using P, ETo, ETc, ETa, WD, WS and S as input variables in the model. The PCA was performed based on the correlation matrix between the components and the normalized variables used to convert a set of observations of possibly correlated variables into a new set of values of principal components, which account for most of the data variability. The eigenvectors and eigenvalues of the variables were obtained for each principal component. The eigenvectors are values that represent the weight of each variable in each component, ranging from -1 to +1 . The eigenvalues are values representing the relative contribution of each component to explain the total variance of the data. Graphically, each principal component is explained in a different axis. In this study, we considered only the two principal axes in the analysis, due to the ease and sufficient explanation of the data in a two-dimensional graph. The number of principal components retained in the analysis was based on the Kaiser criterion (KAISER, 1960), which recommend the use of components with eigenvalues greater than 1 . In the case of correlation of the principal components with the climatic variables, the values greater than 0.7 were considered significant (ZWICK; VELICER 1986).

\section{RESULTS AND DISCUSSION}

The estimated water balances between 1981 and 2011 had the following average values: reference evapotranspiration (ETo $\left.=1,093.2 \mathrm{~mm} \mathrm{yr}^{-1}\right)$, crop evapotranspiration $\left(\mathrm{ETc}=1,041.5 \mathrm{~mm} \mathrm{yr}^{-1}\right)$, actual evapotranspiration ( $\left.\mathrm{ETa}=1,027.2 \mathrm{~mm} \mathrm{yr}^{-1}\right)$, water deficit $\left(\mathrm{WD}=12.7 \mathrm{~mm} \mathrm{yr}^{-1}\right.$ ) and surplus (WS $=574.1 \mathrm{~mm} \mathrm{yr}^{-1}$ ) (see Table 2 for yearly data). Both monthly and yearly average $\mathrm{P}$ appears to be greater than the corresponding ETc during the studied period (Figure 1 and Table 2). Similarly, monthly and yearly average WS was usually higher than WD (Figure 1 and Table 2). The highest WS occurred in $1983\left(1,143.5 \mathrm{~mm} \mathrm{yr}^{-1}\right)$ when P reached $2,166.3 \mathrm{~mm} \mathrm{yr}^{-1}$. The absence of dry season (Figure $2 \mathrm{~A}$ ) allowed limiting the WD to low values over the years. It is important to note that monthly and yearly WD and WS can be higher than zero within the same period of time if this period includes days with non-zero WD and other days with non-zero WS. Under optimal climate conditions and high soil water availability, the ETc for pine forests in Brazil varies from $60 \%$ to $90 \%$ of total precipitation, showing variations depending on climate characteristics (OKI, 2002). In the present study, ETc reaches about approximately $70 \%$ of $\mathrm{P}$, probably due to the combination of high rainfall index and low temperatures, resulting in low vapor pressure deficit and atmospheric demand to evapotranspiration in the region (McVICAR et al., 2012). Also, the relatively low WD and large WS can be explained by the site latitude, altitude, and low solar irradiance. The analyzed area is located in a Oxisol (Table 1) at a high altitude region, which presents small demand for evapotranspiration and high precipitation, resulting in decreased water deficit and increased soil water excess and water storage (Figure 1) (SOUZA et al., 2006). Indeed, the high soil water storage has been reported for the studied site (SOUZA et al., 2016).

The wettest season occurs most frequently between October and March (Figure 1A). The identification of this period is of great importance for management operation planning, mainly over growing season along the year, because both water surplus and deficit can cause severe damage to young trees (BRAZILIAN AGRICULTURAL RESEARCH CORPORATION, 2005). Hence, in Southern Brazil, forest management practices are usually in March or April, with low occurrence of water deficit or surplus. The identification of this trend is also relevant for long-term modeling of variables related to P, such as crop evapotranspiration for pine trees (FORD et al., 2005; LINCOLN et al., 2007). Water surplus generally occurred every month (Figure 1A). The recommended acceptable level of water deficit to fit the pine planting is at most $50 \mathrm{~mm} \mathrm{y}^{-1}$ (CASTRO et al., 2010). In this paper, water storage equal to $183 \mathrm{~mm}$ was considered average and the annual WD was $12.8 \mathrm{~mm} \mathrm{yr}^{-1}$ (Figure 1B).

The excessive soil water content increases the risk of diseases in seedlings (AUER; GRIGOLETTI, 2000), and reduces the development and growth of pine trees (BOGNOLA et al., 2010), while water deficit affects tree growth mainly by its negative impact on the dynamic of nutrients in the soil (BELLOTE; DEDECEK, 2006). The months of April to June stand out as the period of highest deposition of pine litter in Southern Brazil (VIERA; SHUMACHER, 2010). The authors considered that in periods of low rainfall the increased loss of foliage may be a survival physiological strategy, 
avoiding water depletion by transpiration. Precipitation occurrence, especially those observed in previous summers, have great influence on the growth of pine trees and can be used as effective indicators for crop growth (CHANG; AGUILAR, 1980). Based on monthly- and yearly-average P series (Figure 1) and those considerations, Southern Brazil (Parana state) can be considered to have enough rainfall for tree growth.

Table 2. Estimated water balance components for Pinus taeda L., over 31 years in Southern Brazil.

Tabela 2. Componentes do balanço hídrico estimado para Pinus taeda L., ao longo de 31 anos no Sul do Brasil.

\begin{tabular}{|c|c|c|c|c|c|c|c|}
\hline \multirow{2}{*}{ Year } & ETo(1) & $\mathrm{ETc}^{(2)}$ & $\mathbf{P}^{(3)}$ & $P$-ETC & $\mathrm{ETa}^{(4)}$ & $\mathbf{W D}^{(5)}$ & $\mathbf{W S}^{(6)}$ \\
\hline & \multicolumn{7}{|c|}{ 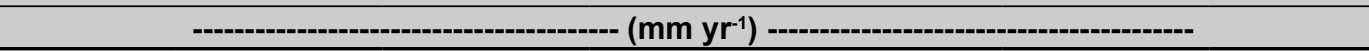 } \\
\hline 1981 & $1,115.9$ & $1,060.1$ & $1,367.0$ & 306.9 & $1,037.6$ & 22.4 & 328.1 \\
\hline 1982 & $1,088.6$ & $1,034.1$ & $1,822.8$ & 788.7 & $1,034.1$ & 0.0 & 789.7 \\
\hline 1983 & $1,021.3$ & $1,014.4$ & $2,166.3$ & $1,151.9$ & $1,014.4$ & 0.0 & $1,143.5$ \\
\hline 1984 & $1,125.1$ & $1,068.9$ & $1,600.8$ & 531.9 & $1,068.9$ & 0.0 & 531.9 \\
\hline 1985 & $1,151.9$ & $1,094.3$ & $1,256.8$ & 162.5 & $1,082.4$ & 11.9 & 361.2 \\
\hline 1986 & $1,076.2$ & $1,022.4$ & $1,830.5$ & 808.1 & 976.1 & 46.4 & 674.5 \\
\hline 1987 & $1,049.1$ & 996.6 & $1,610.7$ & 614.0 & 996.6 & 0.0 & 638.4 \\
\hline 1988 & $1,140.1$ & $1,083.1$ & $1,282.5$ & 199.4 & 953.2 & 129.8 & 271.5 \\
\hline 1989 & $1,069.7$ & $1,016.2$ & $1,877.1$ & 860.9 & $1,016.2$ & 0.0 & 847.4 \\
\hline 1990 & $1,056.2$ & $1,003.4$ & $1,705.5$ & 702.1 & $1,003.4$ & 0.0 & 796.5 \\
\hline 1991 & $1,129.5$ & $1,073.1$ & $1,365.3$ & 292.2 & $1,070.2$ & 2.8 & 220.6 \\
\hline 1992 & $1,081.8$ & $1,074.8$ & $1,914.9$ & 840.2 & $1,027.7$ & 0.0 & 867.3 \\
\hline 1993 & $1,089.5$ & $1,035.0$ & $1,444.6$ & 409.6 & $1,035.0$ & 0.0 & 495.3 \\
\hline 1994 & $1,105.0$ & $1,049.7$ & $1,641.8$ & 592.0 & $1,049.7$ & 0.0 & 506.3 \\
\hline 1995 & $1,011.0$ & 960.4 & $1,496.2$ & 535.7 & 960.4 & 0.0 & 493.0 \\
\hline 1996 & $1,125.2$ & $1,069.0$ & $1,496.2$ & 427.2 & $1,069.0$ & 0.0 & 432.1 \\
\hline 1997 & $1,065.1$ & $1,011.9$ & $1,982.4$ & 970.5 & $1,008.2$ & 3.7 & 928.4 \\
\hline 1998 & $1,118.7$ & $1,062.8$ & $1,545.9$ & 483.1 & $1,062.8$ & 0.0 & 519.4 \\
\hline 1999 & $1,134.2$ & $1,077.4$ & $1,310.8$ & 233.4 & $1,009.2$ & 68.2 & 422.5 \\
\hline 2000 & $1,098.8$ & $1,043.8$ & $1,643.3$ & 599.5 & $1,040.1$ & 3.7 & 447.7 \\
\hline 2001 & $1,100.7$ & $1,045.7$ & 1,733.2 & 687.5 & $1,045.7$ & 0.0 & 702.2 \\
\hline 2002 & $1,137.0$ & $1,080.1$ & $1,579.8$ & 499.7 & $1,080.1$ & 0.0 & 513.2 \\
\hline 2003 & $1,109.9$ & $1,054.4$ & $1,596.1$ & 541.7 & $1,054.4$ & 0.0 & 521.2 \\
\hline 2004 & $1,131.8$ & $1,075.2$ & $1,665.0$ & 589.8 & $1,075.2$ & 0.0 & 649.0 \\
\hline 2005 & $1,119.7$ & $1,063.7$ & $1,340.2$ & 276.5 & $1,063.3$ & 0.4 & 339.9 \\
\hline 2006 & $1,136.1$ & $1,079.3$ & $1,261.4$ & 182.1 & 975.8 & 103.5 & 169.8 \\
\hline 2007 & $1,161.7$ & $1,103.7$ & $1,506.3$ & 402.6 & $1,103.7$ & 0.0 & 395.8 \\
\hline 2008 & $1,106.3$ & $1,051.0$ & $1,382.3$ & 331.3 & $1,049.9$ & 1.1 & 491.4 \\
\hline 2009 & $1,049.2$ & 996.8 & $2,008.1$ & $1,011.3$ & 996.8 & 0.0 & 854.2 \\
\hline 2010 & $1,065.5$ & $1,012.3$ & $1,578.3$ & 566.0 & $1,012.3$ & 0.0 & 582.3 \\
\hline 2011 & 917.5 & 871.6 & $1,764.4$ & 892.8 & 871.6 & 0.0 & 863.7 \\
\hline Average & $1,093.17$ & $1,041.46$ & $1,605.69$ & 564.23 & $1,026.04$ & 12.71 & 574.13 \\
\hline $\mathrm{SD}^{(7)}$ & 49.59 & 45.99 & 236.25 & 260.81 & 47.74 & 31.64 & 228.91 \\
\hline
\end{tabular}

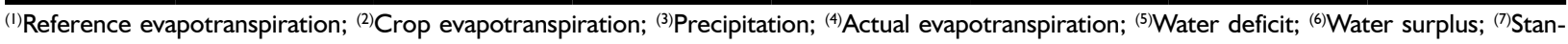
dard deviation.

Due to water surplus, the average monthly soil water storage was close to the total available water in one meter of soil thickness (Figure 1C). Soils with high soil water holding capacity favor water availability for trees to meet the atmospheric demand for water, while soils with low TAW deplete this reserve in short periods of drought. Therefore, water deficit starts before and is more intense in soils with lower TAW. The ability to retain water in the soil is mainly due to soil physical properties that most influence on pine growth (MORRIS et al., 2006). The highest soil water levels, except under conditions of high water surplus, favor the growth increment of pine trees (DEDECEK et al., 2008).

Yearly average S, ETc and ETa are similar to obtained in a previous study in the same area, through a soil water balance with measured data (SOUZA et al., 2016). In addition, similar results were obtained in studies developed with pine trees in the USA, under similar climate conditions to Southern Brazil (FORD et al., 2005; LU et al., 2003). 

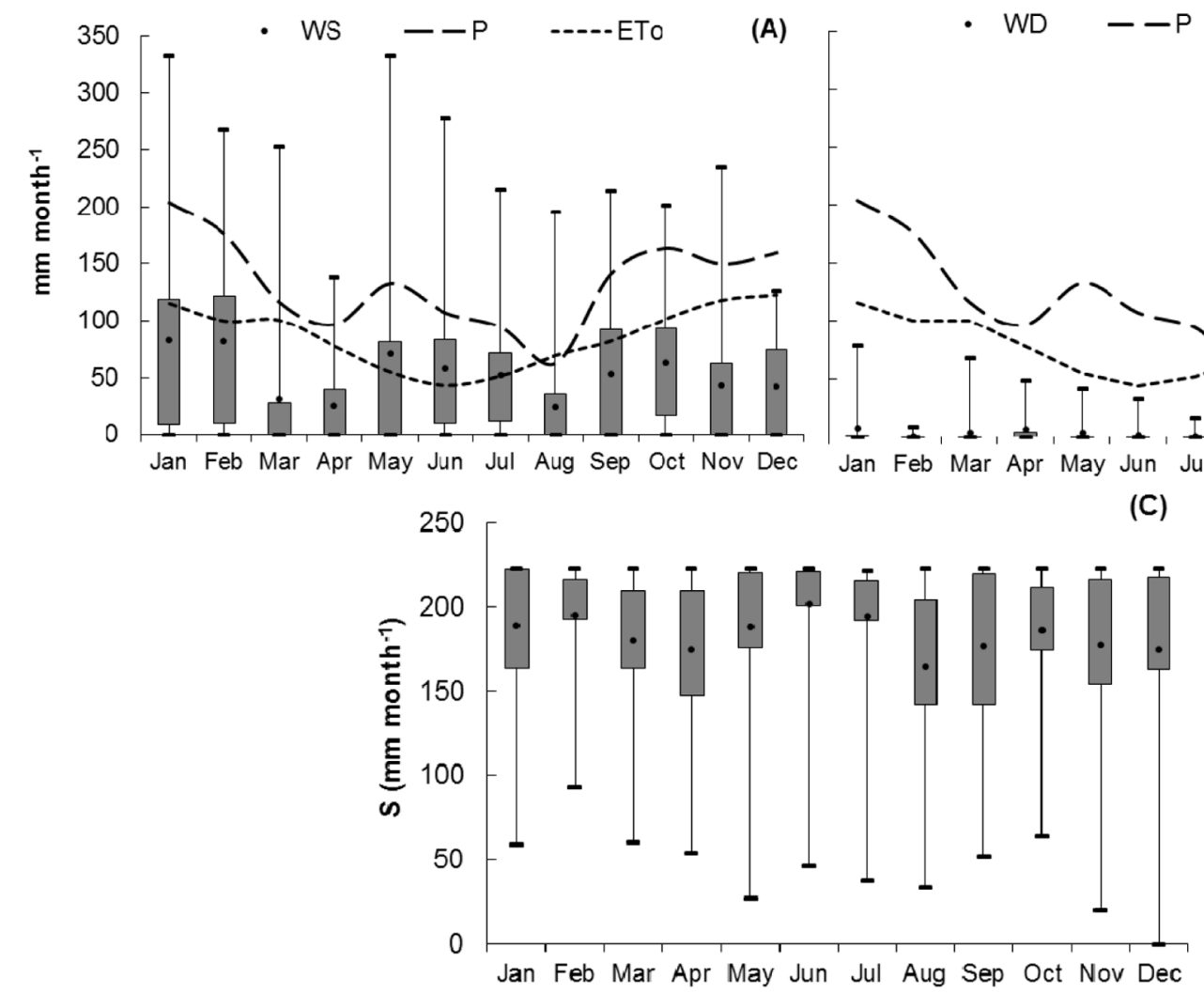

Figure 1. Boxplot of $(A)$ water surplus "WS", (B) water deficit "WD" and (C) soil water storage "S" data series; and, monthly average precipitation " $P$ " and reference evapotranspiration "ETo" over 31 years in Southern Brazil.

Figura 1. Boxplot do (A) excedente hídrico "WS", (B) deficiência hídrica "WD" e (C) armazenamento de água no solo "S"; e, média mensal da precipitação " $\mathrm{P}$ " e evapotranspiração de referência "ETo" ao longo de 31 anos no Sul do Brasil.

Our results demonstrate that estimated water balances are a great tool to understand soil water dynamics and can be used to replace soil water balance for agricultural planning purposes. Water surplus may have a negative influence on plant growth (FARRAR et al., 2000; RAY; NICOLL, 1998), but plasticity to water surplus and deficit has been reported in Pinus (HIGA, 2008).

Figure 2A shows that WS is strongly correlated to P. This result can be useful for the generation of simple models explaining soil-water critical periods. Precipitation does not follow any pattern in a frequency distribution, characterizing its relative randomness, represented by its cyclicity and irregularity (JERSZURKI et al., 2015). Cyclical and irregular variations of P occur owing to climatic oscillations with periodicities greater than one year, such as El Niño and La Niña movements. Those variations can affect climate on a regional and global scale. In Southern Brazil, the years affected by El Niño (considered very strong in 1982-83 and 1997-98) showed an increase in precipitation, especially in spring from May to July, and hence a higher WS. To the contrary, lower precipitation occurred in years influenced by La Niña (considered moderate to strong in 1988-89, 1998-00, 2007 08 and 2010-11).

We observed a slight correlation between WD and P and ETo (Figure 2C and 2D). In that case, it can be stated that the WD was little influenced by the cyclical effects of $\mathrm{P}$ and hence by the El Niño and La Niña. Despite the fact that soil water storage was not well correlated with ETo, it was best explained by the cyclicity of $\mathrm{P}$ (Figures $2 \mathrm{E}$ and $2 \mathrm{~F}$ ). 

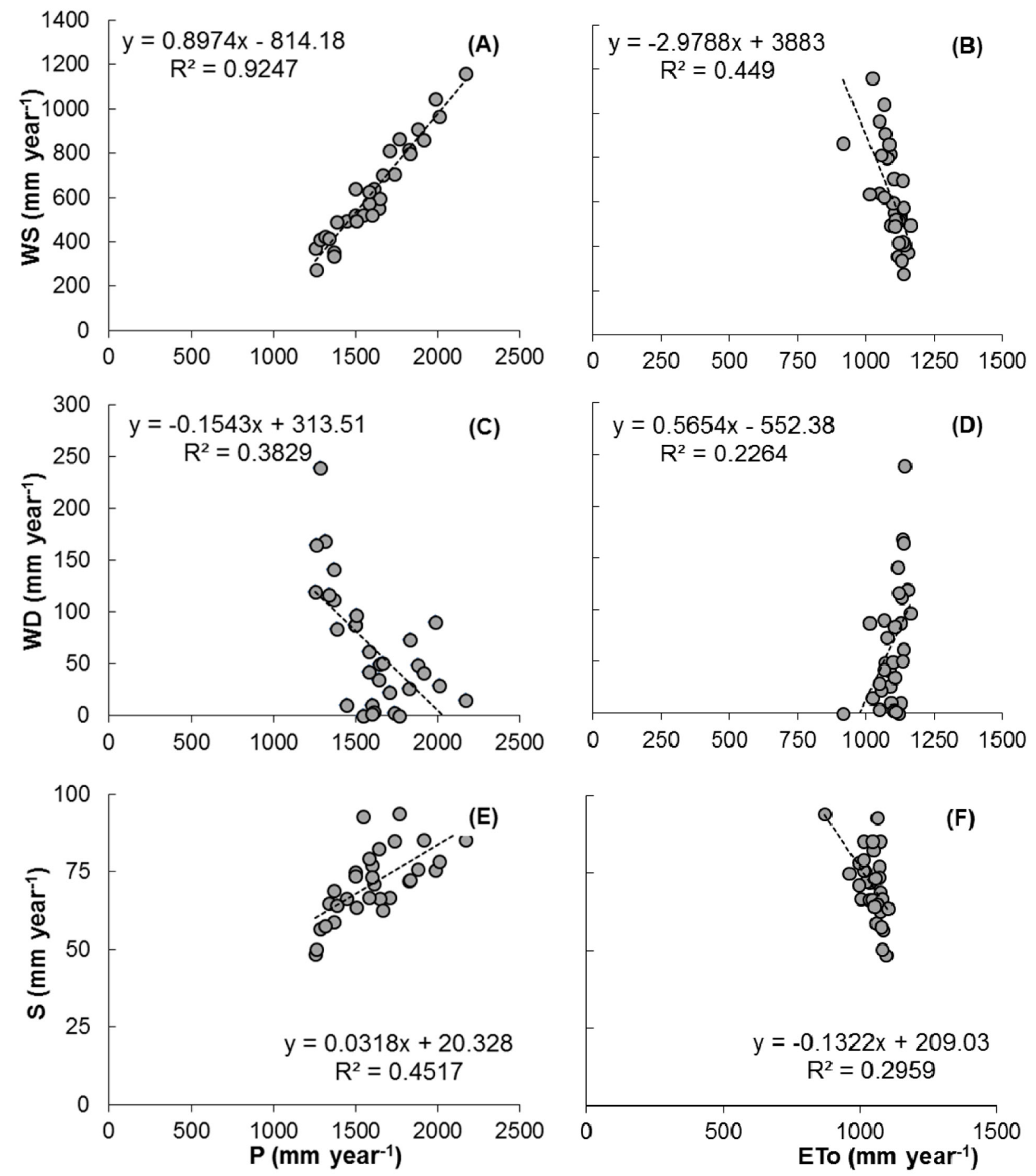

Figure 2. Linear regression and determination coefficient $\left(R^{2}\right)$, for annual values of $(A) P$ and WS; (B) ETo and WS; (C) P and WD; (D) ETo and WD; (E) P and S; and, (F) ETo and S over 31 years in Southern Brazil.

Figura 2. Análise de regressão linear e coeficiente de determinação $\left(R^{2}\right)$, para os valores anuais de $(A) P$ e WS; $(B)$ ETo e WS; (C) P e WD; (D) ETo e WD; (E) P e S; e, (F) ETo e S ao longo de 31 anos no Sul do Brasil.

Principal component analysis (PCA) were performed in order to determine relationships between the water balance components and find the most important components on soil-water monitoring (Figure 3). 

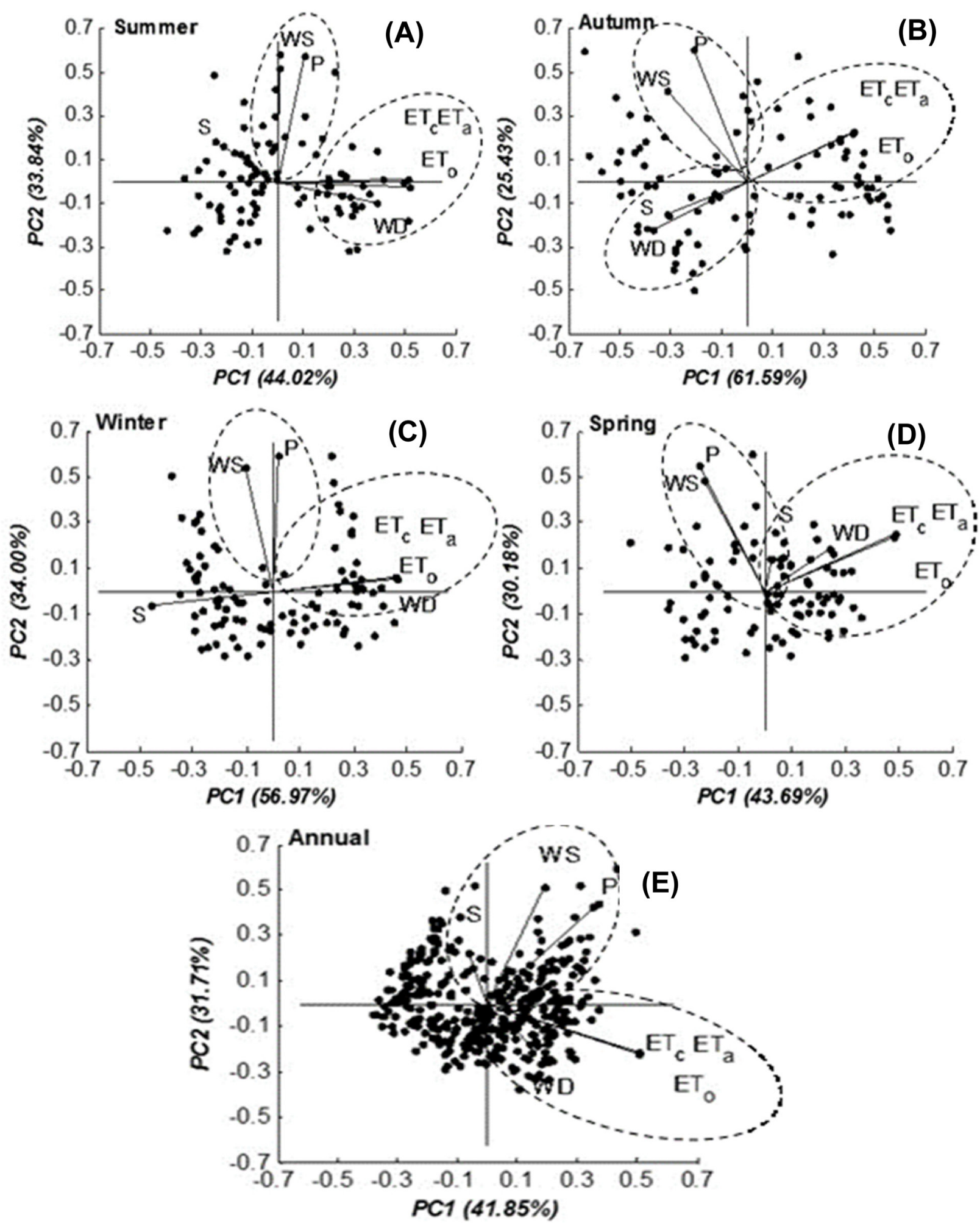

Figure 3. Principal component analysis of precipitation (P), reference evapotranspiration (ETo), crop evapotranspiration (ETc), actual evapotranspiration (ETa), water deficit (WD), water surplus (WS), and soil water storage (S) of a water balance over 31 years for seasonal (summer, autumn, winter and spring) and annual periods, in Southern Brazil: (A) summer; (B) autumn; (C) winter; (D) and spring; and (E) annual.

Figura 3. Análise de componentes principais da precipitação $(P)$, evapotranspiração de referência (ETo), evapotranspiração da cultura (ETc), evapotranspiração real (ETa), deficiência hídrica (WD), excedente hídrico (WS) e armazenamento de água no solo (S) do balaço hídrico estimado ao longo de 31 anos, para o período estacional (verão, outono, inverno e primavera) e anual, no Sul do Brasil: (A) verão; (B) outono; (C) inverno; (D) primavera; e (E) ano.

In general, we observed different results over seasons, indicating that seasonality has an influence on the comparison of water balance components. For all periods, the first component (PC1) was related to atmospheric demand, explaining between $46.43 \%$ to $64.66 \%$ of data variability over sea- 
sons, being strong and positive correlated to ETo, ETc, ETa and WD for all periods, except in summer and autumn; confirming its largest variability over time. It can be stated that water deficit is more related to the occurrence of higher evapotranspiration than lower precipitation, especially in the wet season. Interestingly, in autumn WD becomes negatively correlated to ET components (i.e. higher ET provoke lower water deficit) and positively correlated with S (Figure 3B). The beginning of this season is marked by high S, ETc and ETa, which start to decrease over time, until the beginning of winter (Figure 3C). Despite this fact, the decrease of $S$ and high ETc was not enough to impact the increase of WD. In addition, the effect of $\mathrm{P}$ may impact the decrease of water deficit. Moreover, by definition water deficit only occurs when soil water storage is less than soil water availability, which indicates restriction to soil water removal, promoting weak correlations between WD and another water balance components (Figures 2E and 2F). The second component (PC2) was related to soil water supply, which explained from $21.40 \%$ to $25.91 \%$ of data variability over seasons and was strong and positively correlated to P and WS. The strong correlation between P and WS (Figure 2A) determined the variability of water surplus (Figure $1 \mathrm{~A}$ ). We observed a scattering pattern of $\mathrm{S}$, which was strong and negatively correlated to the PC1, mainly in autumn and winter seasons. However, $\mathrm{S}$ did not present a strong correlation with ETo or P, for all periods, probably due to the equation used to its estimate. The Cosine equation is the most efficient model to estimate $S$ in estimated water balances (DOURADO NETO et al., 1993; SOUZA; GOMES, 2007), however, since it considers only the influence of TAW and $\mathrm{p}$ fraction for the estimation, it is not directly affected by ETa, ETc, ETo, and P.

\section{CONCLUSION}

The response of soil water storage, water deficit and water surplus to the most important input variables in the water balance model were analyzed in the subtropical climate in Brazil, to find the most important water balance components on soil-water monitoring. Precipitation and evapotranspiration were used in the analysis, which revealed diverse effects on water balance components over seasons. In general, precipitation regulates water surplus, while reference evapotranspiration regulates water deficit. Even if soil water storage was not significantly affected by precipitation and evapotranspiration, it impacts the response of water surplus and deficit to the input variables in the estimated water balance. We conclude that accurate estimates of evapotranspiration have a key role in estimating water balances.

\section{REFERENCES}

ABRAF - ASSOCIAÇÃO BRASILEIRA DE PRODUTORES DE FLORESTAS PLANTADAS. Anuário Estatístico 2013 Ano base 2012. Brasília: ABRAF, 2013. 142 p.

ALLEN, R. G.; PEREIRA, L. S; RAES, D.; SMITH, M. Crop evapotranspiration: guidelines for computing crop water requirements. Rome: Food and Agriculture Organization of the United Nations, 1998.

ÁLVARES, C. A.; STAPE, J. L.; SENTELHAS, J. L.; GONÇALVEZ, J. L.; GERD, S. Koppen's climate classification map for Brazil. Meteorologische Zeitschrift, Stuttgart, v. 22; p. 711-728, 2013.

ARAUJO, M. Tillage and soil water relations in the soybean yield in Ponta Grossa - Paraná. Scientia Agraria, Curitiba, v.10, p.403-412, 2009.

AUER, C. G.; GRIGOLETTI JUNIOR, A. Queima de ponteiros de mudas de Pinus taeda. Comunicado Técnico da EMBRAPA, Colombo, n. 43, p. 1-2, 2000.

BELlOTE, A. F. J.; DEDECECK, R. A. Soil physical and chemical attributes and their relation to Pinus taeda growth and productivity. Boletim de Pesquisa Florestal, Colombo, v. 53, p. 21-38, 2006.

BOGNOLA, I. A.; DEDECECK, R. A.; LAVORANTI, O. J; HIGA. A. R. Influence of soil physical characteristics on growth of Pinus taeda. Pesquisa Florestal Brasileira, Colombo, v. 30, p. 37-49, 2010. 
Jerszurki et al. - Water balance output components are distinctly regulated by

precipitation and evapotranspiration in Pinus taeda L. plantations in Southern Brazil

EMBRAPA - EMPRESA BRASILEIRA DE PESQUISA AGROPECUÁRIA. EMBRAPA Florestas. Colombo: Embrapa Florestas, 2005. 34 p.

BRUNO, I. P.; SILVA, A. S.; REICHART, K.; DOURADO, NETO, D.; BACHI, O. O S.; VOLPE, C. A. Comparison between climatological and field water balances for a coffee crop. Scientia Agricola, Piracicaba, v. 64, p. 215220, 2007.

CASTRO, F. S.; PEZZOPANE, J. E. M.; PEZZOPANE, J. R. M.; CECÍLIO, R. A.; XAVIER, A. C. Agroclimatic zoning for cultivation of Pinus in the State of Espirito Santo. Revista Floresta, Curitiba, v. 40, p. 235-250, 2010.

CHANG, M.; AGUILAR, G. J. R. Effects of climate and soil on the radial growth of loblolly pine (Pinus taeda L.) in a humid environment of the southeastern U.S.A. Forest Ecology and Management, Amsterdam, v. 3, p. $141-150,1980$.

DEDECK, R. A.; FIER, I. S. N.; SPELTZ, R.; LIMA, L. C. S. Site influence on 22-years-old Pinus taeda growth: 1. Soil physico-hydrical and chemical characteristics. Revista Floresta, Curitiba, v. 38, p. 507-516, 2008.

DOURADO NETO, D.; VAN LIER, Q. J.; METSELAAR, K.; REICHERDT, K.; NIELSEN, D. R. General procedure to initialize the cyclic soil water balance by Thornthwaite and Mather method. Scientia Agricola, Piracicaba, v. 67, p. $87-95,2010$.

DOURADO NETO, D.; JONG, L; VAN LIER, Q. Estimativa do armazenamento de água no solo para realização de balanço hídrico. Revista Brasileira de Ciência do Solo, Viçosa, v. 17, p. 9-15, 1993.

FARRAR, J. J.; NUNEZ, J. J.; DAVIS, R. M. Influence of soil saturation and temperature on Erwinia chrysanthemi soft rot of carrot. Plant Disease, Minnesota, v. 84, p. 665-668, 2000.

FORD, C.R.; GORANSON, C. E.; MITCHELL, R. J.; WILL, R. E.; TESKEY, R. O. Modeling canopy transpiration using time series analysis: A case study illustrating the effect of soil moisture deficit on Pinus taeda. Agricultural and Forest Meteorology, Netherlands, v. 130, p. 163-175, 2005.

GONG, L.; CHU, C. H.; CHEN, D.; HALDIN, S.; CHEN, Y. D. Sensitivity of the Penman-Monteith reference evapotranspiration to key climatic variables in the Changjiang (Yangtze River) basin. Journal of Hydrology, Netherlands, v. 329, p. 3-4, 2006.

GURSKI, B. C.; SOUZA, J. L. M.; JERSZURKI, D.; ARMINDO, R. A.; EVANGELISTA, A. W. P. Periodicity of crop coefficient and soil water depletion fraction in a climatological water balance. African Journal of Agricultural Research, v. 11, p. 4619-4626, 2016.

HIGA, R. C. V. Agroclimatic zoning: Pinus taeda on the South of Brazil, Colombo: Embrapa florestas, 2008. $78 \mathrm{p}$.

JERSZURKI, D.; SOUZA, J. L. M.; EVANGELISTA, A. W. Probability distribution and time movements of precipitation in Telêmaco Borba; Paraná; Brazil. Agrária, Recife, v. 10, p. 110-116, 2015.

IPCC - NTERGOVERNMENTAL PANEL ON CLIMATE CHANGE. Climate Change 2014: Impacts; Adaptation; and Vulnerability. United Kingdom and New York: Cambridge Press, 2014. 688 p.

KAISER, H. F. The application of electronic computers to factor analysis. Educational and Psychological Measurement, California, v. 20, p. 141-151, 1960.

KIRKHAM, M. Principles of Soil and Plant Water Relations. 2 ed. Manhattan: Academic Press, 2014. 598 p. 
LEMOS FILHO, L. C. A.; MELO, C. R.; FARIA, M. A.; CARVALHO, L. G. Spatial-temporal analysis of water requirements of coffee crop in Minas Gerais State. Brazil. Agrária, Recife, v. 14, p. 165-172, 2010.

LINCOLN, M. C.; RODNEY, E.; MORRIS, L. A. Soil change and loblolly pine (Pinus taeda) seedling growth following site preparation tillage in the Upper Coastal Plain of the southeastern United States. Forest Ecology and Management, Amsterdam, v. 242, p. 558-568, 2007.

LIQIAO, L.; LI, L.; ZHANG, L.; LI, B. Sensitivity of the Penman-Monteih reference crop evapotranspiration in Taover river basin of northeastern China. Chinese Geography Science, v. 18, p. 340-347, 2008.

LU, J.; SUN, G.; MCNULTY, S. G.; AMATYA, D. M. Modeling actual evapotranspiration from forested watersheds across the Southeastern United States. Journal of American Water Resources Association, New Jersey, v. 39, p. 887-896, 2003.

McNULTY, S.G.; BOGGS, J.L.; SUN, G. The rise of the mediocre forest: why chronically stressed trees may better survive extreme episodic climate variability. New Forests, Berlin, v. 45, p. 403-415, 2014.

MCVICAR, T. R. RODERICK, M. L.; DONOHUE, R. J.; LI, L. T.; NIEL, T. G. V.; THOMAS, A.; GRIESER, J.; JHAJHARIA, D.; HIMRI, Y.; MAHOWALD, N. M.; MERSCHERSKAYA, A. V.; KRUGER, A. C.; REHMAN, S.; DINPASHOH, Y. Global review and synthesis of trends in observed terrestrial near-surface wind speeds: implications for evaporation. Journal of Hydrology, Netherlands, v. 416, p. 182-205, 2012.

MORRIS, L. A.; LUDOVIC, K. H.; TORREANO, S. J.; CARTER, M. C.; LINCOL, M. C.; WILL, R. E. An approach for using general soil physical condition-root growth relationships to predict seeding growth response to site preparation tillage in loblolly pine plantations. Forest Ecology and Management, Amsterdam, v. 227, p. 169-177, 2006.

OKI, K. V. Impactos da colheita de Pinus taeda sobre o balanço hídrico, a qualidade da água e a ciclagem de nutrientes em microbacias. 2002. 85 p. Dissertação (Mestrado em Ciências Florestais) - Escola Superior de Agricultura "Luiz de Queiroz", Universidade de São Paulo, Piracicaba, 2002.

PEREIRA, A. N. Symplifying the Thornthwaite-Mather water balance. Bragantia, Campinas, v. 64, p. 311-313, 2005.

PRACIAK, A. The CABI encyclopedia of forest trees. Oxford: CABI, 2013. 523 p.

RAY, D.; NICOLL, B.C. The effect of soil water-table depth on root-plate development and stability of Sitka spruce. Forestry, London, v. 71, p. 169-182, 1998.

ROSA, H.; MARTINS, S. S.; SILVA, O. H. Forest activity in the counties of Telêmaco Borba; Ortigueira; Reserva; Imbau and Tibagi: characterization and perspectives of the site. Acta Scientiarum Agronomy, Maringá, v. 28, p. 41-45, 2006.

SOUZA, J. L. M.; FRIZZONE, J. A. Water balance simulation for coffee crop in two regions of the Minas Gerais State; Brazil. Scientia Agraria, Curitiba, v. 8, p. 291-301, 2007.

SOUZA, J. L. M.; GOMES, S. Evaluation and performance of soil water storage equations in a decadal climatic water balance for irrigation. Acta Scientiarum Agronomy, Maringá, v. 29, p. 433-443, 2007.

SOUZA, J. L. M.; FEZER, K. M.; GURSKI, B. K.; JERSZURKI, D.; PACHECHENIK, P. E. Soil water balance in different densities of Pinus taeda in Southern Brazil. Acta Scientiarum Agronomy, Maringá, v. 38, p. 265-271, 2016. 
Jerszurki et al. - Water balance output components are distinctly regulated by

precipitation and evapotranspiration in Pinus taeda L. plantations in Southern Brazil

SOUZA, M. J. H.; RIBEIRO, A.; LEITE, H. G.; LEITE, F. P.; MINUZZI, R. B. Soil water availability and eucalyptus productivity in three regions of the Rio Doce basin. Revista Árvore, Viçosa, v. 30, p. 399-410, 2006.

THORNTHWAITE, C. W.; MATHER, J. R. The water balance. Drexel Institute of Technology - Laboratory of Climatology. Publications in Climatology, v. 8, p. 104, 1955.

VIERA, M.; SCHUMACHER, M. V. Monthly variation of litter deposition in Pinus taeda L. stand in native grass area in Cambará do Sul - RS. Revista Árvore, Curitiba v. 34, p. 487-494, 2010.

WARD, E. J.; DOMEC, J. C.; LAVINER, M. A.; FOX, T. R.; SUN, G.; MCNULTY, S.; KING, J.; NOORMETS, A. Fertilization intensities drought stress: Water use and stomatal conductance of Pinus taeda in a mid rotation fertilization and through fall reduction experiment. Forest Ecology and Management, Amsterdam, v. 355, p. 72-82, 2015.

ZWICK, W. R.; VELICER, W. F. Comparison of five rules for determining the number of components to retain. Psychological Bulletin, Washington, v. 99, p. 432-442, 1986.

Received in 2017/05/03

Accept in 2018/02/15 